\title{
Suspended particulate matter in the White Sea: the results of long-term interdisciplinary research
}

\author{
MARINA KRAVCHISHINA, ALEXEY KLYUVITKIN, ALEXANDER FILIPPOV, \\ ALEXANDER NOVIGATSKY, NADEZHDA POLITOVA, \\ VLADIMIR SHEVCHENKO \& ALEXANDER LISITZIN
}

P.P. Shirshov Institute of Oceanology of the Russian Academy of Sciences, Russia kravchishina@ocean.ru

\begin{abstract}
The spatial and temporal variations in SPM concentration in the White Sea, Russia, are directly (mineral particles from the water basin) or indirectly ("blossom" of diatoms due to supply of nutrients) caused by river runoff. Interannual variations in SPM concentration for the White Sea are low and do not exceed 18\% (2003-2010); hence, they are statistically insignificant.
\end{abstract}

Key words suspended particulate matter; chlorophyll a; Arctic; White Sea, Russia; remote sensing; grain size; organic matter

\section{INTRODUCTION}

Suspended particulate matter (SPM) consists of mineral and organic particles of different size ranging from half a micron to several millimetres. The SPM is the main source of bottom sediments and an indicator of sedimentary processes and pathways of particulate substances (including contaminants). In the seas of the Russian Arctic and subArctic, including the White Sea, it is poorly studied. We started research in the White Sea, Russia, in 2000. In this paper the research aims at studying the spatial and temporal variability in the SPM concentration and its main composition in the White Sea using both remote sensing and field observations for acquiring new knowledge about sedimentation processes in the Arctic, as well as making an evaluation of land-ocean interaction in the Arctic Region. This is an important problem for the planned expansion of operations and investigations in the Arctic. The White Sea can be seen as a testing ground for the study of land-ocean interaction in the Arctic shelf seas because this sea is easily accessible for regular investigations. Several problems were covered during the present study:

(a) Generalization of information on the SPM and chlorophyll $a$ (Chla) for the 13-year period (2000-2012) of studies in the White Sea. Chla is not only a parameter used for primary production (PP) calculations, Chla and its derivatives may also be used as markers for assessing the labile forms of organic carbon $\left(\mathrm{C}_{\text {org }}\right)$ in seawater, where these molecules solely characterize the impact of phytoplankton on organic matter (OM) (Stephens et al. 1997).

(b) Obtaining and analysis of satellite data (MODIS-Aqua colour scanner).

(c) Study of the SPM composition (grain size, mineral composition and OM content).

(d) Foundation of the marine SPM sources.

(e) Revealing any regularity in the spatial and temporal variability in the SPM concentrations.

\section{STUDY AREA}

The Arctic Ocean experiences enormous continental runoff (e.g. Gordeev and Rachold 2003), dominated by major Eurasian rivers such as the Northern (or Severnaya) Dvina flowing into the White Sea (Fig. 1). The mouth area is represented by the multichannel delta, $900 \mathrm{~km}^{2}$ in extent. The bulk of the terrigenous matter is supplied to the White Sea with riverine runoff in May (Fig. 2). The White Sea is the smallest of six marginal shelf seas of the Eurasian Arctic, with an average water depth $67 \mathrm{~m}$ and a maximum water depth of $343 \mathrm{~m}$ in the central basin (Berger et al. 2001). It is an enclosed sea, located at the Arctic Circle that can be considered as a sub-extreme environment (Pantyulin 2003). The White Sea connects with the Barents Sea through the quite 


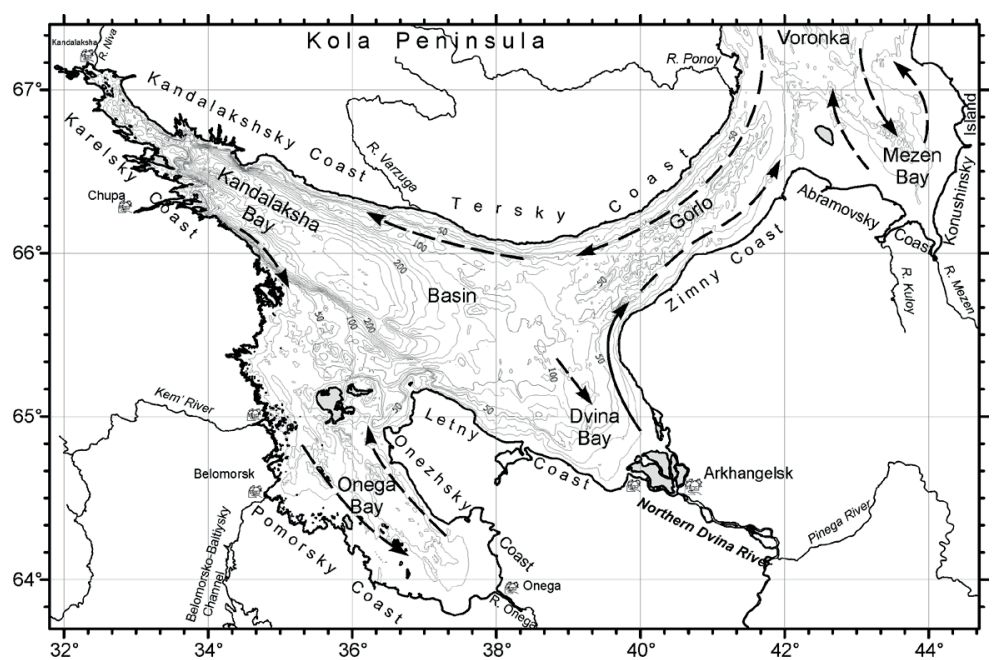

Fig. 1 Map of the White Sea, its bathymetry (based on IO RAS and GEBCO bathymetry) and major currents (data from Pantyulin 2003).

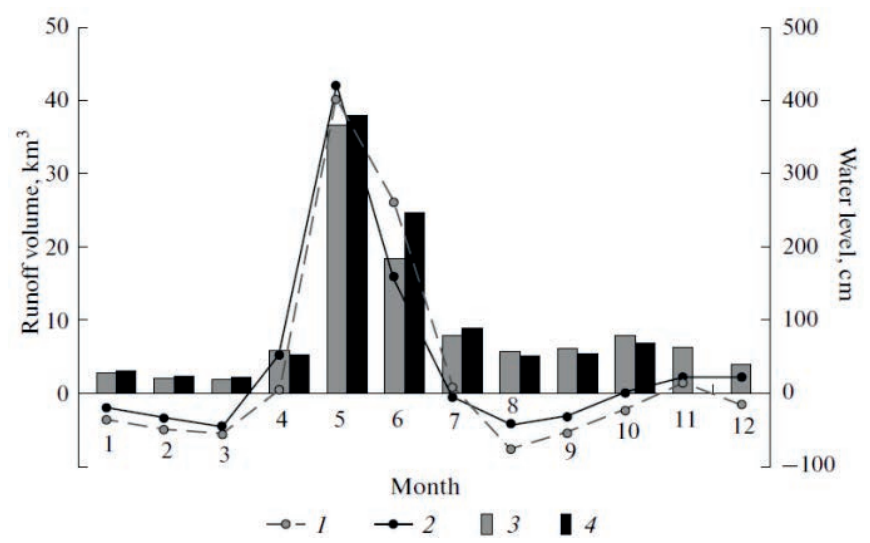

Fig. 2 Annual distribution of the levels and runoff in the mouth area of the Northern Dvina River (at the Ust'-Pinega hydrological station) (Kravchishina et al. 2010), courtesy Pleiades Publishing, Inc. 1: level, long-term average data; 2: level in 2004; 3: runoff volume 1881-1980; 4: runoff volume, 2004.

narrow Gorlo Strait. It is characterized by a brief vegetative period (about six months). All the rivers of the drainage area are characterized by lower turbidity as compared with the rivers of East Siberia. Despite the fact that the river water's turbidity is relatively low, the total volume of terrigenous SPM appears to be significant owing to the high annual flow $\left(215 \mathrm{~km}^{3}\right)$.

\section{MATERIALS AND METHODS}

The material for this study was collected in the interdisciplinary expeditions organized by the P. P. Shirshov Institute of Oceanology of the Russian Academy of Sciences. Our research is based on 3500 samples of SPM in the water column collected during 20 cruises (2000-2012) during open water periods. Water samples were taken using Niskin bottles, taking account of hydrooptical and hydrophysical sounding data. The SPM mass concentration was determined by the standard technique of vacuum filtering at $0.4 \mathrm{~atm}$ using membrane filters (diameter $47 \mathrm{~mm}$, pore diameter $0.45 \mu \mathrm{m}$ ) (Cutter et al. 2010). The chemical composition of SPM was examined, the flow of suspended and dissolved matter from rivers was analysed, and marine phyto- and bacterio plankton were studied (Kravchishina et al. 2008, Ilyash et al. 2011). The Multisizer 3 modification of a Coulter counter ( $\sim 2000$ samples) was used for the study of the concentration by volume and grain size of the SPM (Mercus 2009). The measurements of the Chla concentration in the water (326 samples) were performed by fluorometry using the Trilogy 1.1 fluorometer (Turner Designs) 
(Arar and Collins 1997). To analyse the spatial distribution of the SPM and Chla concentration and its variations, data from the MODIS-Aqua colour scanner were used (http://oceancolor. gsfc.nasa.gov/).

We chose 195 pairs of simultaneous measurements of the marine brightness coefficient and SPM concentration made during 2003-2010 (May to September). Based on the data for two spectral channels of the MODIS-Aqua colour scanner, 531 and $551 \mathrm{~nm}$, the parameter of backward scatter by suspended particles $\left(b_{b p}, \mathrm{~m}^{-1}\right)$ was calculated (Burenkov et al. 2011). The algorithm to find the SPM concentration is based on a regression relationship between SPM and $b_{b p}$, which is written for the White Sea as follows (Burenkov et al. 2011, Lisitzin et al. 2013):

$$
S P M=22.8 b_{b p}{ }^{0.53}, n=195, r^{2}=0.70
$$

where $b_{b p}$ is particle backscattering coefficient, $\mathrm{m}^{-1}$ (wavelength $555 \mathrm{~nm}$ ); $S P M$ is in $\mathrm{mg} / \mathrm{L}$. The regression equation obtained for the White Sea, connecting $b_{b p}$ and SPM, significantly differs from the equations for other seas, including the Barents Sea (Kopelevich et al. 2004).

A total of 68 measurements of the seawater radiance reflectance derived from data of the MODIS-Aqua ocean colour scanner were used to compare with the same number of results of direct measurements, with both datasets referring to each other by the date and location of sampling. These results were used to develop the algorithm for regional usage (Kravchishina et al. 2013):

$$
\text { Chla }=2.13\left(R_{r s}(531) / R_{r s}(547)\right)^{-2.42}, n=65, r^{2}=0.61
$$

where $R_{r s}$ is the sea luminosity coefficient for the spectra channels of $531 \mathrm{~nm}$ and $547 \mathrm{~nm}$, and Chla is the concentration of Chla, $\mu \mathrm{g} / \mathrm{L}$.

\section{RESULTS}

\section{Mass concentration of the SPM}

The average SPM concentration beyond the river mouths is $\sim 1.0 \mathrm{mg} / \mathrm{L}$ in summer; according to our data this value exceeds the same parameter for the Barents Sea by 3-4 times and is twice that for the Kara Sea. The interannual variations in the average values are insignificant: from 0.5 to $1.1 \mathrm{mg} / \mathrm{L}$. Higher values of SPM concentration $(>1 \mathrm{mg} / \mathrm{L})$ are usually detected in the mouth parts of rivers and located usually in a narrow (up to $20 \mathrm{~km}$ wide) coastal zone.

SPM concentration may be changeable due to wind mixing and tide phase. After the storm of July 2010 (intensity was up to 4 on the Beaufort scale), the water turbidity in the surface layer increased by approx. 1.5-2 times. Using the ADCP, the SPM dynamics dependence on the tidal cycle was studied at the diurnal stations: (a) the SPM concentration peaks in the high tide period, while it increases at low tide; (b) variations in the SPM concentration have been found within the whole water column of 1.5 times or even more, both in the coastal zone and in the distant zone.

The temperature and density stratification of the water column and, as a consequence, SPM stratification (two or three layers) is most pronounced in the deep part of the sea. Density deformation of the vertical structure of the water column in summer forms a so-called "liquid bottom", where a significant part of the SPM is collected (usually at a depth of 5-20 m). Beneath the pycnocline the SPM concentration decreases by 3-4 times. The thickness of the near-bottom nepheloid layer ranges from a few metres to a few tens of metres (average 10-20 m). The SPM concentration in the nepheloid layer of the White Sea (up to $5 \mathrm{mg} / \mathrm{L}$ in the shallow area) is close to values in the nepheloid layer of the Barents Sea. However, the turbidity and thickness of these layers is usually much lower than in the Kara, Laptev and East Siberian seas.

\section{Chlorophyll $a$ concentration}

According to our observations, the average concentration of Chla in the photic layer usually exceeds $1 \mu \mathrm{g} / \mathrm{L}$ (reaching $9 \mu \mathrm{g} / \mathrm{L}$, and sometimes $21 \mu \mathrm{g} / \mathrm{L}$, in the shallow inlets of the bays), i.e. the threshold for characterizing the waters as eutrophic. The thickness of photic layer in the White Sea is $10-15 \mathrm{~m}$ on average (Kravchishina et al. 2013). In summer, the maximal concentration is observed in the surface water layer (about $0-10 \mathrm{~m}$ ), sometimes in the very surface layer of $0-5 \mathrm{~m}$. 
When the water column is well stratified, a peak of Chla concentration is observed above the thermocline. Below the thermocline, the concentration of Chla decreases greatly with increased depth: down to $0.5 \mu \mathrm{g} / \mathrm{L}$ and lower in the transitional (depth range of 20-60 m) and near-bottom water masses originating from the Barents Sea. The concentration of Chla in the White Sea is significantly higher compared to the Barents Sea and the Pechora Sea, and is similar to the Kara Sea, which is also affected strongly by intensive riverine discharge.

\section{Satellite (calculated) data of the SPM mass concentration}

Maps of the average monthly distribution of the SPM concentration, with $2 \mathrm{~km} \times 2 \mathrm{~km}$ spatial averaging, are given in Fig. 3 (see also the digital atlas available from http://optics.ocean.ru). The average annual values for the White Sea are presented in Table 1.
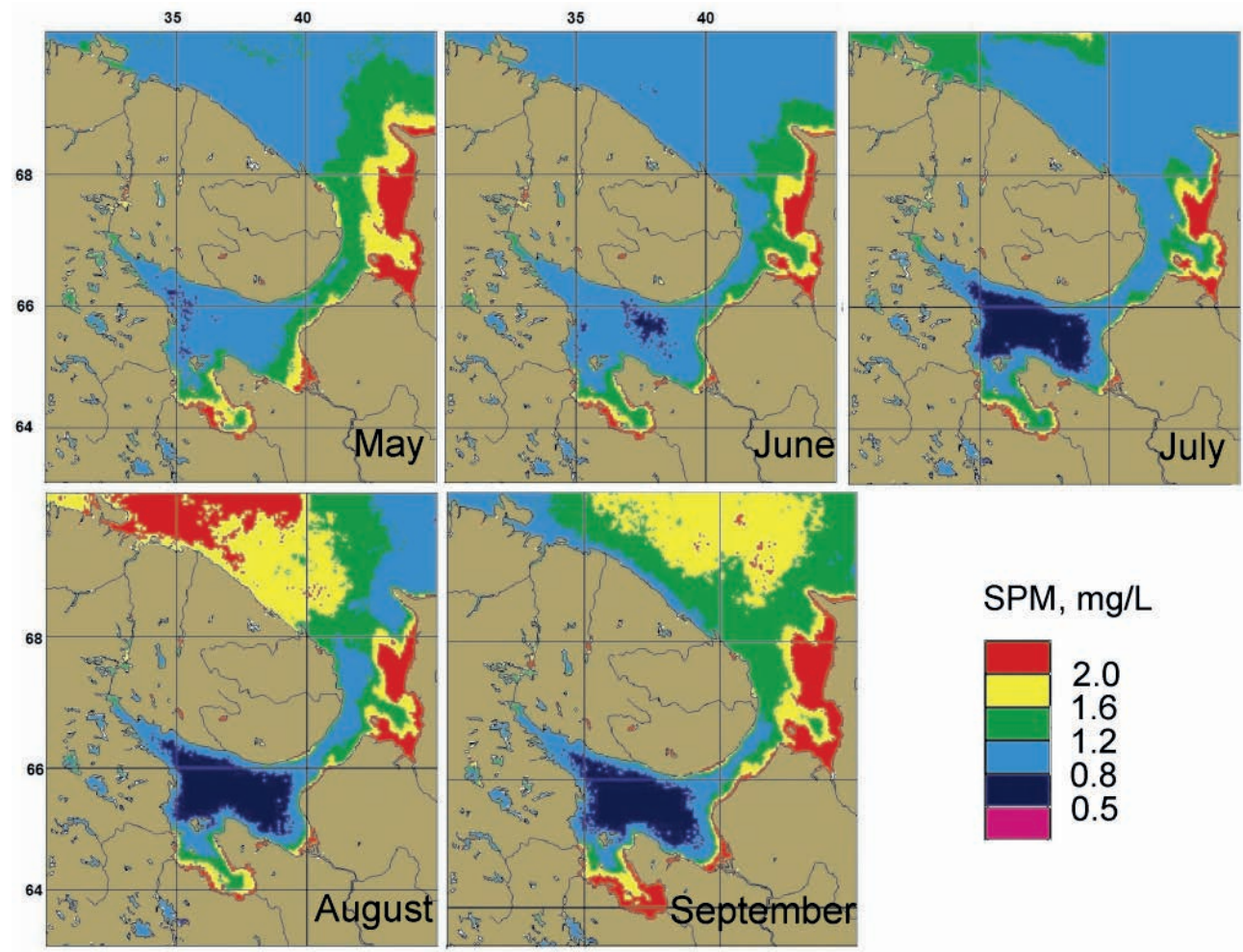

Fig. 3 Average monthly values of the SPM concentration based on the data from MODIS-Aqua satellite colour scanner. Images are composites over May-September in 2003-2010, provided by IO RAS Ocean Optic Laboratory, http://optics.ocean.ru (Burenkov et al. 2011).

Table 1 Calculated average annual values of SPM and Chla concentration and their mean square deviations in the White Sea according to MODIS-Aqua satellite observations.

\begin{tabular}{lll}
\hline Years & $\begin{array}{l}\text { SPM } \\
(\mathrm{mg} / \mathrm{L})\end{array}$ & $\begin{array}{l}\text { Chl } a \\
(\mu \mathrm{g} / \mathrm{L})\end{array}$ \\
\hline 2003 & $1.39 \pm 0.20$ & $2.18 \pm 0.18$ \\
2004 & $1.35 \pm 0.12$ & $2.23 \pm 0.11$ \\
2005 & $1.36 \pm 0.09$ & $2.23 \pm 0.09$ \\
2006 & $1.41 \pm 0.10$ & $2.18 \pm 0.05$ \\
2007 & $1.33 \pm 0.13$ & $2.16 \pm 0.13$ \\
2008 & $1.34 \pm 0.16$ & $2.14 \pm 0.09$ \\
2009 & $1.40 \pm 0.11$ & $2.21 \pm 0.12$ \\
2010 & $1.41 \pm 0.09$ & $2.27 \pm 0.12$ \\
$2003-2010$ & $1.37 \pm 0.12$ & $2.20 \pm 0.11$ \\
\hline
\end{tabular}


Real measurements, which are highly local ("point") in the spatial sense and nearly "instant" in the temporal sense, can show higher variations than satellite data averaged over area $(2 \mathrm{~km} \times$ $2 \mathrm{~km}$ ) and time (day-month-year). Analysis of the seasonal and interannual variations in the SPM and Chla concentration from satellite data has allowed us to reveal the characteristic features of these variations in the period discussed (2003-2010) (Kravchishina et al. 2013, Lisitzin et al. 2013).

\section{Concentration by volume of the SPM}

The SPM concentration by volume in the White Sea varies from 0.2 to $5 \mathrm{~mm}^{3} / \mathrm{L}$, the average value is $\sim 1.0 \mathrm{~mm}^{3} / \mathrm{L}$. The highest concentrations are influenced by the river runoff area $\left(>5 \mathrm{~mm}^{3} / \mathrm{L}\right)$. High numbers of micro-organisms, up to 558000 cells $/ \mathrm{ml}$, were found (Kravchishinaet al. 2008). The study of the concentrations with the Coulter counter demonstrated good consistency with the data obtained by the traditional method of SPM extraction using vacuum filtration in the White Sea $\left(y=0.98 x+0.16, n=345, r^{2}=0.67\right)$.

\section{Specific surface area of the SPM}

Specific surface area of the SPM varies from 4000 to $13000 \mathrm{~cm}^{2} / \mathrm{ml}$ in the White Sea. The SPM has a developed surface (especially in the areas of the river's mouth) and correspondingly high sorption capacity of the particles. The developed surface of the SPM may also indicate higher biogeochemical activity of its particles. We revealed the influence of the pelitic fraction $(<10 \mu \mathrm{m})$ content on the abundance of bacteria in different parts of the sea in summer (Kravchishina et al. 2008).

\section{Grain size distribution}

On average, the SPM consists of 70-80\% pelitic fractions $(2-10 \mu \mathrm{m})$, i.e. the share of silt and sand fractions accounts for only $20-30 \%$. The predominant fraction $(2-5 \mu \mathrm{m})$ content is usually less than 50\%. Particles do not pass the full mechanical (according to specific weight) and biological separation in the water body. The high content of pelitic fraction clearly marks the pathways of transformed river waters of the Northern Dvina (Kravchishina and Lisitzin 2011).

\section{Mineral composition of the SPM}

According to X-ray diffraction analyses (42 samples) the share of clay minerals in the SPM is $40 \%$ and higher. Almost half of the crystalline phase of the SPM consists of clay minerals. Among them, the primary role belongs to illite $(35-57 \%$ of the amount of clay in the fraction $<10 \mu \mathrm{m})$. A high content of illite was found in pelitic $(<10 \mu \mathrm{m})$ and in subcolloidal $(<1 \mu \mathrm{m})$ fractions. Smectite was found in relatively large amounts $(8-30 \%)$, which has the greatest dispersity and tends to subcolloidal fraction (Saukel et al. 2010, Kravchishina and Dara 2014). Chlorite and kaolinite content varies from 15 to $27 \%$. A similar composition of clay minerals in SPM was found typical for other Russian Arctic seas (Kara, Laptev), which have exposed large plain rivers crossing several natural zones (Müller and Stein 1999). The fine clastic part of the minerals were present in the SPM everywhere, both in coastal parts and in the open sea. Among them, quartz and feldspars provide basic background (50\%). The fine grains of these minerals reach the open sea areas, enriching the pelitic fraction of muds during sedimentation processes.

\section{Biogenic particles and $\mathrm{OM}$}

The fraction of phytoplankton particles (based on the phytoplankton biomass) in the total SPM content in the White Sea reaches $60-65 \%$. The content of terrigenous particles decreases with distance from the river mouths, although remains quite high (Kravchishina and Lisitzin 2011). Comparison of the SPM concentrations by volume $\left(0.5-5 \mathrm{~mm}^{3} / \mathrm{L}\right)$ with the amount of phytoplankton $\left(0.12-3.65 \mathrm{~mm}^{3} / \mathrm{L}\right)$ has shown the following fractions of phytoplankton in the SPM in 
different regions of the sea: $27 \%$ in the vertex of Dvina Bay, $40 \%$ in the basin, and $65 \%$ in Kandalaksha Bay (Ilyash et al. 2011).

Content of $\mathrm{C}_{\text {org }}$ in the SPM varies from 5 to $30 \%$ (automatically measured by the culonometric method). In the Northern Dvina River mouth area, all the seasons are characterized by the dominant role of the dissolved OM. Dissolved $\mathrm{C}_{\text {org }}$ largely represents a conservative allochthonous substance dominated by humic components (up to $60-80 \%$ ) liable to association, condensation, and formation of polydispersive systems and complexes with metals (Gordeev and Rachold 2003).

\section{DISCUSSION}

The data from the colour scanner characterize the upper (a few metres at most) part of the White Sea; this roughly corresponds to the layer where the maximal concentrations of SPM and Chla are recorded $(0-5 \mathrm{~m}$, rarely at deeper horizons).

The distribution and dynamics of SPM within the active layer are determined by the sources of SPM. In the open water period the sources are allochthonous material (mostly transported by flows of large rivers) and autochthonous (biogenic) material. Allochthonous material is supplied primarily by the Northern Dvina River (the peak is during high water in May), and this is seen explicitly from the satellite SPM maps. The distribution of autochthonous material is determined by production of phytoplankton, as reflected by the satellite maps of Chla distribution. In the beginning of the hydrological spring, the main sources are kryosols and algal flora supplied during melting of sea and river ice.

The values of the SPM concentration decrease by a factor of 5-10 with distance off the coast. In the coastal zone the SPM concentration depends mostly on the conditions of the wind and waves and tidal mixing of water, and sorting of the matter supplied from land in terms of hydraulic size. In river mouths the SPM distribution is mostly determined by isohaline positions: the SPM concentration decreases exponentially by up to $79 \%$ as salinity increases (Kravchishina and Lisitzin 2010). In the basin, increased SPM concentration $(>1 \mathrm{mg} / \mathrm{L})$ is usually related to local growth of phytoplankton associations, under the condition of biogenic substances and photosynthetically available radiation (PAR) being available.

The greatest amplitude of the average annual variations in the SPM concentration is observed in Dvina, Onega and Mezen bays, and in the eastern part of Gorlo-Voronka region, i.e. in the water areas affected by river runoff. But the greatest relative difference between the average annual values for different years is $18 \%$. Hereinafter, the significance value is 0.05 (confidence probability is $95 \%$ ). The minimal average annual value of the SPM concentration for the entire sea was observed in 2007, the year of lowest ice coverage in the Arctic region.

Based on the satellite data, the interannual linear trends of sea surface temperature, SPM concentration, Chla content, and yellow matter absorption have been estimated; these estimates have shown the absence of a significant trend for the discussed period of 2003-2010. The variability of annual averages of the Chla concentration was assessed. For the study period, it did not exceed $8 \%$. We revealed the similarity of seasonal dynamics of Chla and the SPM concentrations. This is primarily preconditioned by the same factor, i.e. by the riverine discharge, which carries both SPM and nutrients to the sea.

The maximal concentration of Chla $(3-9 \mu \mathrm{g} / \mathrm{L})$ was registered during the summer period at depths of $0-5 \mathrm{~m}$ and rarely in deeper layers. Most of the OM is synthesized by the phytoplankton during photosynthetic processes in a relatively shallow surface water layer of $0-10 \mathrm{~m}$, i.e. in the most biochemically-active water layer.

\section{CONCLUSIONS}

Based on the field observation data, the SPM concentration in the White Sea's active layer is $\sim 1 \mathrm{mg} / \mathrm{L}$, on average. The primary sources of SPM in the White Sea have been found: mineral particles of river origin and marine phytoplankton. First of all, this is suspended material supplied from the Northern Dvina River basin with water flow. Chla concentration (marker of PP) is preconditioned by the same factor - riverine discharge, which carries not only SPM, but also 
nutrients. Interannual variations in SPM concentration for the White Sea are low and, based on our multi-annual calculations, do not exceed $18 \%$. Hence, they are statistically insignificant. It was shown that the SPM concentration cannot be a criterion for assessing the effects of climate warming in the Arctic.

Acknowledgements The authors are grateful to O.V. Kopelevich, V.I. Burenkov, S.V. Vazuylya and S.V. Sheberstov for help in analysing the satellite data. This study was supported by the Program of Basic Studies of the Presidium of the Russian Academy of Sciences (no. 23, paragraph 10.1), the Russian Foundation for Basic Research (project no. 12-05-91055-NCNI, 14-05-00223-a), President Grant NSh-2493.2014.5 for Leading Scientific Schools.

\section{REFERENCES}

Arar, E.J. and Collins, G.B. (1997) Method 445.0. In vitro determination of chlorophyll a and pheophytin a in marine and freshwater algae by fluorescence. Revision 1.2. Cincinnati: US Environmental Protection Agency.

Berger, V., et al. (2001) White Sea. Ecology and Environment. St. Petersburg: Derzavets.

Burenkov, V.I., et al. (2011) Space-time variability of suspended matter in the White Sea derived from satellite ocean color data. In: Proceedings VI International Conference "Current Problems in Optics of Natural Waters" (ed. by O. Kopelevich and C. Trees), 143-146. St.-Petersburg: Nauka.

Burenkov, V.I., Goldin, Yu.A. and Kravchishina, M.D. (2010) The distribution of the suspended matter concentration in the Kara Sea in September 2007 based on ship and satellite data. Oceanology 50(5), 799-806.

Cutter, G., et al. (2010) Sampling and sample-handling protocols for GEOTRACES cruises. Version 1.0. 144. Available from: http://www.geotraces.org/libraries/documents/Intercalibration/Cookbook.pdf

Gordeev, V.V. and Rachold, V. (2003) Modern terrigenous organic carbon input to the Arctic Ocean. In: Organic Carbon Cycle in the Arctic Ocean: Present and Past. River Input (ed. by R. Stein and R.W. MacDonald), 33-41. Berlin: Springer.

Ilyash, L.V., et al.(2011) Spatial variability of the species composition, abundance, and productivity of the phytoplankton in the White Sea in the late summer period. Oceanology 51(1), 19-26.

Kopelevich, O.V.,et al. (2004) Application of SeaWiFS data for studying variability of bio-optical characteristics in the Barents, Black and Caspian Seas. Deep-Sea Research II 51, 1063-1091.

Kravchishina, M.D., et al. (2008) Relationship between the suspended particulate matter and microorganisms in the White Sea waters. Oceanology 48(6), 837-854.

Kravchishina, M.D., et al. (2010) Composition of the suspended particulate matter at the Severnaya Dvina River mouth (White Sea) during the spring flood period. Oceanology 50(3), 365-386.

Kravchishina, M.D., et al. (2013) New data on the spatial and temporal variability of the chlorophyll $a$ concentration in the White Sea. Doklady Earth Sciences 448(1), 120-125.

Kravchishina, M.D. and Dara, O.M. (2014) Mineral composition of the SPM in the White Sea. Oceanology 54(3).

Kravchishina, M.D. and Lisitzin, A.P. (2011) Grain-size composition of the suspended particulate matter in the Marginal Filter of the Severnaya Dvina River. Oceanology 51(1), 89-104.

Lisitzin, A.P., et al.(2013) Spatial and temporal variability in suspended particulate matter concentration within the active layer of the White Sea. Doklady Earth Sciences 453(2), 1228-1233.

Mercus, H.G. (2009) Particle size measurements: fundamentals, practice, quality. Springer Science+Business Media B.V.

Müller, C. and Stein, R. (1999) Grain-size distribution and clay-mineral composition in surface sediments and suspended matter of the $\mathrm{Ob}$ and Yenisei rivers. Ber. Polarforsch. 300, 179-187.

Pantyulin, A.N. (2003) Hydrological system of the White Sea. Oceanology 43, S1-S14.

Saukel, C., et al. (2010) Clay-mineral and grain-size distributions in surface sediments of the White Sea (Arctic Ocean): indicators of sediment sources and transport processes. Geo-Mar Lett. 30, 605-616.

Stephens, M.P., et al. (1997) Chlorophyll $a$ and pheopigments as tracers of labile organic carbon at the central equatorial Pacific seafloor. Geochim. et Cosmochim. Acta 61(21), 4605-4619. 